\title{
DIE GESAG VAN DIE PREDIKING VAN DIE NUWE TESTAMENTIESE BRIEWE (1)
}

\author{
Dr. B. J. de Klerk
}

\section{Motivering, Begrensing en Metode}

\subsection{Motivering}

Die Nuwe-Testamentiese Briewe is ontvouingsprediking van die sentrale waarheid dat God Hom in Sy Seun geopenbaar het, en hulle is daarom in die Skrif van beslissende en grondleggende betekenis. Wie dus ondersoek na die gesag van die Skrif wil instel, kan dit ook vanuit die hoek van die Nuwe-Testamentiese Briewe doen, want die Briewe belig juis God se spreke, God se seggenskrag, deur Sy Seun.

Die Briewe as geheel en elkeen afsonderlik kom met die aanspraak dat hulle gesaghebbende prediking is (vgl. 1 Ts. $2: 13 ; 1 \mathrm{Jn} .4: 6$; Rm. 9: 1; $3 \mathrm{Jn} .12$; Gl. 1 : 18). Die skrywers oefen daadwerklik gesag oor hulle lesers uit, en die lesers luister en reageer op die prediking. Die reaksie van die lesers op die mondelinge en skriftelike prediking kan uit die Briewe vasgestel word. Op hulle beurt interpreteer die skrywers dan die hoorders se reaksie op die prediking en lewer op grond daarvan ingrypende uitsprake, wat selfs die lesers se eindbestemming raak. En vandag, eeue na die skryf van die Briewe, is daar nog steeds op die aansprake van die Briewe uiteenlopende reaksies. Die prediking van die Briewe dwing met sy aanspraak tot 'n uitspraak: erkenning of verwerping van die gesag.

Wat is die geheim van die skrywers? Waarom oefen hierdie soort geskrifte van die Nuwe Testament nou nog (soos sedert hulle ontstaan) so 'n sterk invloed op die leser se lewe, op die kerklike praktyk en veral op die insig in die openbaring van die Drie-enige God uit? Dit is ten diepste die "probleem" waaroor dit in my ondersoek gegaan het. Dit is die geheim wat ek probeer naspeur het.

Dat die Skrifvraagstuk vandag nog net so uitdruklik in die brandpunt van die Nuwe-Testamentiese vakwetenskaplike werk staan Van der Walt $(1974: 1-20)$, word weerspieël in die hewige diskussie wat oor vraagstukke in hierdie verband gevoer word. Dit bly dus noodsaaklik om bydraes op hierdie hoogs omstrede terrein te lewer, veral omdat een aspek in hierdie navorsing te maklik buite rekening gelaat word en daarom verwaarloos word. Dit is om die brandpunt op 'n Bybelboek of groep boeke te plaas en na te speur wat die Bybelboeke self van hulle gesag sẽ.

Ons staan vandag nog midde-in die vloedgolf van die Skrifkritiek wat van enkele geskrifte van individue uit radikale kringe gevorder het tot agendapunte op kerklike vergaderings van kerke wat uit die Reformasie stam (vgl. die Acta Gereformeerde Kerken Nederland 1969-1978). En uit die kritiese Skrifbeskouing volg noodwendig 'n kritiese Skrifverklaring, waaruit talle moderne teologiese strominge gebore word.

Dit is dus noodsaaklik om te midde van hierdie diskussies weer vanuit die Reformatoriese beginsels na die Skrifvraagstuk te kyk. Die Reformasie het die grondslag vir ' $n$ benaderingswyse gelê waardeur met betrekking tot die gesag van die Skrif na die Skrif self geluister word. Die beginsel wat in so ' $n$ benadering geld, is die outopistie van die Skrif en die Testamonium Spiritus Sancti. Tog was daar in een opsig 'n tekortkoming en dit is in die erkenning van die historiese karakter van Skrif. Ridderbos bring vernuwing in 1955 (Ridderbos 1955) as hy met behulp van heilshistoriese kategoriee 
die aard van die gesag van die Nuwe Testament ontdek. Hy dui in breè trekke die nuwe koers aan wat nou met detailondersoeke na die verskillende soorte geskrifte van die Nuwe Testament opgevolg moet word (De Klerk (1976); Venter (1980); Rabali (1981)).

Die Briewe van die Nuwe Testament het 'n besondere plek in die geskiedenis van die openbaring. Dit is ontvouingsprediking van die groot heilsgebeurtenisse (Snyman 1977 : 139 e.v.), en die Briewe is self ook deel van die heilsgebeurtenisse.

'n Studie wat verdere lig op die gesag van die Briewe kan werp, behoort vir die volle Teologiese Wetenskap bruikbaar te wees, want die formulering van die gesag, wat vir die Skrifbeskouing bepalend is, is vir die ekklesiologiese, dogmatologiese en diakoniologiese vakke van grondliggende betekenis.

\subsection{Begrensing}

Die ondersoek is op die gesag van die prediking van die Nuwe Testamentiese Briewe gerig, en so word die studie onmiddellik tot die Nuwe Testament self beperk. Binne die Nuwe Testamentiese wetenskap lê die ondersoek op die terrein van die Algemene Kanoniek. Daar is sterk raakpunte met die eksegese en hermeneutiek, en die ondersoek kan in 'n sekere sin ook op die terrein van die Openbaringsgeskiedenis val.

Daar is gepoog om met die een-n-twintig briewe 'n verteenwoordigende snit te maak en die briewe wat gekies is, is: Galasiërs, die twee aan die Korintiërs, 1 Tessalonisense, 1 en 2 Petrus, 1 Johannes en perikope uit Romeine, Hebreërs en Jakobus.

As daar van die gesag van die prediking van die Briewe gepraat word, moet dit nie gesien word as 'n afgrensing binne die Briewe, asof net sekere dele van die Briewe wel prediking is en die res nie is nie. Met die benaming "prediking" word die openbaringshistoriese karakter van die Briewe aangedui.

Die uitgangspunt van hierdie ondersoek is om na die uitsprake van die Briewe oor hulle gesag te luister. En juis dit begrens die ondersoek nog verder. Dit is 'n tetiese ondersoek wat, slegs waar dit noodsaaklik is, eksegetiese resultate van Nuwe Testamentici weeg maar wat geensins die bedoeling het om ander standpunte oor die gesag van die Nuwe Testament - veral standpunte wat vanuit filosofiese of buite-Bybelse voorveronderstellings werk - te beoordeel nie.

\subsection{Metode}

Die bron van die ondersoek is die Griekse Nuwe Testament in sy bestaande vorm, en daarom word daar nie na sogenaamde oerbronne agter die Nuwe Testament gesoek nie. Hier sal ook geensins 'n poging aangewend word om 'n sogenaamde rekonstruksie van enigeen van die Briewe aan te bied nie.

Die waardering vir die bron bepaal ook die metode wat in hierdie geval 'n eksegeties- of openbaringshistoriese metode is - eksegeties, omdat dit vir hierdie ondersoek met ' $n$ bepaalde uitgangspunt inhou dat Skrif met Skrif vergelyk word en dat daarmee die Heilige Gees as die Skrifverklaarder erken word. Van die gedagtestruktuurontledingsmetode is nuttig gebruik gemaak.

Met die openbaringshistoriese metode is gedifferensieerd te werk gegaan. Deur 'n horisontale perspektief word 'n geheelblik oor al die Briewe gesoek, en by kardinale uitsprake word dieptesnitte gemaak. Laasgenoemde word dan op tematiese wyse behandel, veral ook omdat die aard van die Briewe hierdie benadering vereis. 
Die waardering van die bron, die Nuwe Testament, gee ook ten opsigte van die werkplan die deurslag. Die briefskrywers maak aanspraak op gesag, en van deurslaggewende belang is dus die bepaling van die gesagsbron en die persoon van die gesagsdraer. Waarop rus die aansprake en hoe fundeer die briefskrywers hulle gesag? Die tweede stap was om die aard van die aansprake te ondersoek. Wat is die tipiese karakter van die gesag van die prediking van die briewe? Die volgende stap vloei hieruit voort, want die briefskrywers maak nie net daarop aanspraak dat hulle gesag het nie, maar hulle gebruik ook hierdie gesag. Daar sal dus gepoog word om vas te stel hoe die gesag van die Briewe funksioneer.

Hierop volg nog 'n noodwendigheid. As die skrywers aansprake maak en daarmee 'n beroep op die lesers doen, sal vasgestel moet word wat die reaksie van die lesers is. Kan die uitwerking van die gesag van die prediking gekontroleer word?

Geen eksegeet kan sonder voorveronderstellings die Skrif benader nie. Die objektiefste eksegeet is die eksegeet wat hom uitdruklik van sy voorveronderstellings vergewis het en deeglik daarmee rekening hou (vgl. Coetzee, De Klerk, Floor, $1980: 12-26$ ).

Met die erkenning van die Bybel as Woord van God word aangedui dat die Bybel God se Woord in mensewoorde is wat deur die werking van die Heilige Gees deur mense opgeskryf is. Die goddelike en menslike faktor word deurgaans ten volle in die oog gehou. Verder word erken dat die Bybelskrywer (die Heilige Gees) ook dié Bybelverklaarder is (Braaten, 1965 : 234).

'n Verdere voorveronderstelling is die beskouing van die Skopus van die Skrif. Die bepaalde siening van die bedoeling, intensie en gerigtheid van die sentrale inhoud en boodskap van die Nuwe Testament, nl. die openbaring van God in sy Seun, speel 'n beslissende rol in die ondersoek. Daarmee saam word die historiese betroubaarheid van die Nuwe-Testamentiese Briewe erken.

\section{Die Fundering van die Gesag}

Die leser van die een-en-twintig briewe kom onder die indruk van die gesaghebbende skryfstyl van elke skrywer. Nie alleen word uiters belangwekkende uitsprake oor onder andere die Drie-enige God, diep lewenskwessies en die bestemming van die mens gemaak nie, maar talle sinne gebruik die bevelvorm, en aan die lesers word pertinente voorskrifte gegee. Waarop sou die aansprake berus en die briefskrywers hulle gesag fundeer? Verder duik vrae op soos: Is daar 'n bepaalde gesagsbron? Lê die gesag in die persoon self? Is hy met die gesag van 'n ander beklee? Berus die uitsprake op ander gesagdraende uitsprake en watter faktore in die skrywer se eie ervaring speel ' $n$ rol in 'n gesaghebbende uitspraak?

Die ondersoek spits hom hier op drie geskrifte toe (Galasiërs (1: 1024), 2 Petrus (1:16-21) en 1 Johannes $(5: 6-12)$.

2.1 Galasiërs

2.1.1'n Verkorte struktuur van Galasiërs

Paulus omskryf in die eerste twee hoofstukke sy apostelskap breedvoerig en dit gelees vanuit die benaderingshoek van die twee kernverse $(3: 13$, 14 en $5: 1$ ), bring drie fasette van die brief duidelik na vore: die ware evangelie (hfst. 1 en 2$)$, die geloof in Christus $(3: 13,14)$ en die vryheid van die Gees $(5: 1)$. Paulus stel dit teenoor die wettisisme van sy teenstanders. Die tema kan soos volg geformuleer word: "Die kern van die ware evangelie: 
Geloof in Christus gee die vryheid van die Gees". Die brief word soos volg verdeel:

a. Teenoor die wettisisme die ware evangelie $(1: 6-2: 21)$

b. Teenoor die wettisisme die geloof in Christus $(3: 1-4: 31)$

c. Teenoor die wettisisme die vryheid van die Gees $(5: 1-6: 10)$.

Paulus gebruik nie sy apostoliese gesag los van die verband van sy brief nie; inteendeel, hy gebruik juis sy gesag om die lesers weer by die kern van die evangelie te bring.

Die brandpunt val op die eerste twee hoofstukke en hierdie deel kan soos volg verdeel word:

Teenoor die wettisisme die ware evangelie

a. Daar is net een ware evangelie $(1: 6-9)$

b. Die oorsprong van die ware evangelie $(1: 10-24)$

c. Die toets van die ware evangelie $(2: 1-10)$

d. Die onverbiddelike konsekwentheid wat die ware evangelie eis (2:11-14)

e. Die gevolgtrekking en appèl: glo in die ware evangelie $(2: 15-21)$

Die apostel plaas sy uitsprake oor die fundering van sy gesag aan die begin van sy brief om as basis vir die res van sy ontvouingsprediking te dien. Sy evangelie is die eerste skakel in die ketting om via geloof in Christus die Gees te ontvang, en so kan die gelowiges volkome van die verslawende wettiese en/of goddelose bande vrykom. Die eerste twee hoofstukke is die fondament van die gebou waaruit die inhoud van die boodskap (Christus se verlossing, hfst. 3,4) as muur en die gevolg van die geloof en die gehoorsaamheid aan die boodskap (naamlik vervulling met die Gees. hfst. 5) as dak verrys.

2.1.2 Gl. $1: 10-24$

Wanneer Paulus sy verkondiging (in $1: 6-9$ ) met die enigste ware evangelie identies stel, moet hy dadelik sy stelling in Gl. 1 : 10-24 fundeer. On dit te kan doen word eers 10 as skakelvers gebruik.

Die vraag wat Paulus in die vers stel, is vol ironie: Is die taal wat hy in verse 6-9 gebruik het, daarop ingestel om mense te wen en om hulle te vertel wat hulle graag wil hoor? Die vraag is nog skerper wanneer yup nie as redegewend beskou word nie; deur dit met dan te vertaal word die dringendheid van die vraag onderstreep (Oepke $1964: 26$ ). Die Judaiste, wat onder andere hierdeur mense in die war bring, beskuldig Paulus dat hy probeer om by mense gewild te wees en dat hy mense tevrede wil stel. Hy antwoord hierop met twee argumente. Die eerste is dat hy geen motiewe het om mense ter wille van persoonlike gewildheid te wen nie en die tweede. wat nog sterker is, dat hyself nie die outeur van die evangelie is nie, maar dat hy as "slaaf van Christus" die woorde van Christus betroubaar weergee. 2.1.2.1 Gedagtestruktuurontleding van Gl. $1: 10-24$

'n Gedetailleerde gedagtegang kan soos volg weergegee word:

Vgl. bl. 6.

Paulus volg in hierdie gedeelte 'n besonder opvallende struktuur wat die volgende duidelike patroon vertoon.

Vgl. bl. 7 .

In die lig van die ontdekte gedagtestruktuur kan Paulus se gesagsaansprake in Gl. $1: 10-24$ nou nagegaan word.

2.1.2.2 God neem die inisiatief

Paulus is in geen enkele opsig apologeties teenoor sy teenstanders nie, maar 
a. Reaksie van teenstanders op Paulus se prediking (afgelei)

b. Vra aandag vir 'n belangrike aankondiging

c. Die evangelie is nie van menslike oorsprong nie maar 'n openbaring van God

d. Bewyse vir hierdie waarheid

e. God neem die inisiatief in die gee van die openbaring

f. Bewyse vir hierdie waarheid

g. Vra aandag vir voorafgaande deel

h. Reaksie van gelowiges op Paulus se prediking

\begin{tabular}{l|l|} 
vs 10 & Inleiding \\
vs 11a & $\begin{array}{l}\text { Vertrekpunt/ } \\
\text { beklemtoning }\end{array}$ \\
vs 11b - \\
12 & Eerste hoofdeel \\
vs 13,14 & $\begin{array}{l}\text { Uitbouing 1ste } \\
\text { deel }\end{array}$ \\
vs 15, & Tweede hoofdeel \\
$16 \mathrm{~b}$ & \\
vs $16 \mathrm{c}-$ & $\begin{array}{l}\text { Uitbouing 2de } \\
\text { deel }\end{array}$ \\
vs 20 & Beklemtoning \\
vs $21-$ & Slot \\
24
\end{tabular}

gebruik hulle beskuldiging om op ' $n$ ondubbelsinnige wyse sy gesaghebbende prediking te fundeer. Die redes wat hy in 1:10-24 aanvoer, vorm 'n eenheid, en daarin kan primêre en sekondêre elemente onderskei word: die belangrikse vir Paulus is dat dit God behaag het, wat hom afgesonder en geroep het, om sy Seun in hom te openbaar, en daaruit vloei voort dat geen mens, op watter wyse ook al, hierin 'n rol gespeel het nie. Vers 15, 16a beskryf die verskillende dele van die apostel se instelling in die diens: Eerstens God se bestemming met die apostel van ewigheid en ook die afsondering tot die diens van sy geboorte af. Dan volg sy bekering en roeping tot apostel op die pad na Damaskus (Hd. 9 : 20). Van die Damaskusgebeurtenis is daar net in die verbygaan sprake omdat die klem hier op die oorsprong van sy evangelie val en nie soseer op sy afhanklikheid as apostel nie (Burton, 1984 : 49). Alles dui op die een groot saak, naamlik dat God die inisiatief geneem het.

Die $\delta \varepsilon$ stel vers 15 teenoor Paulus se aktiwiteite in die verlede wat in

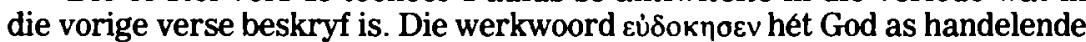
Persoon en leer dat Paulus bloot ontvanger is. God handel uit vrye welbehae, en Paulus ontken hiermee dat sy vermoèns of insig enige rol kon gespeel het.

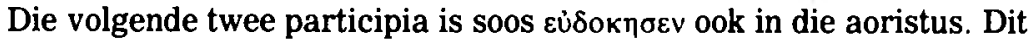
wys dus op 'n konkrete handeling wat afgehandel is en waaroor daar geen twyfel kan bestaan nie. God het hom van sy geboorte af aangewys en vir sy apostelskap afgesonder. Die woord $a \varphi \rho \circ \zeta \zeta \omega$ beteken om iets of iemand vir 'n spesifieke doel eenkant te plaas. Sy geboorte, sy opvoeding, ontwikkeling en lewensloop gee alles blyke van God se genadige bestiering. Dit gaan 


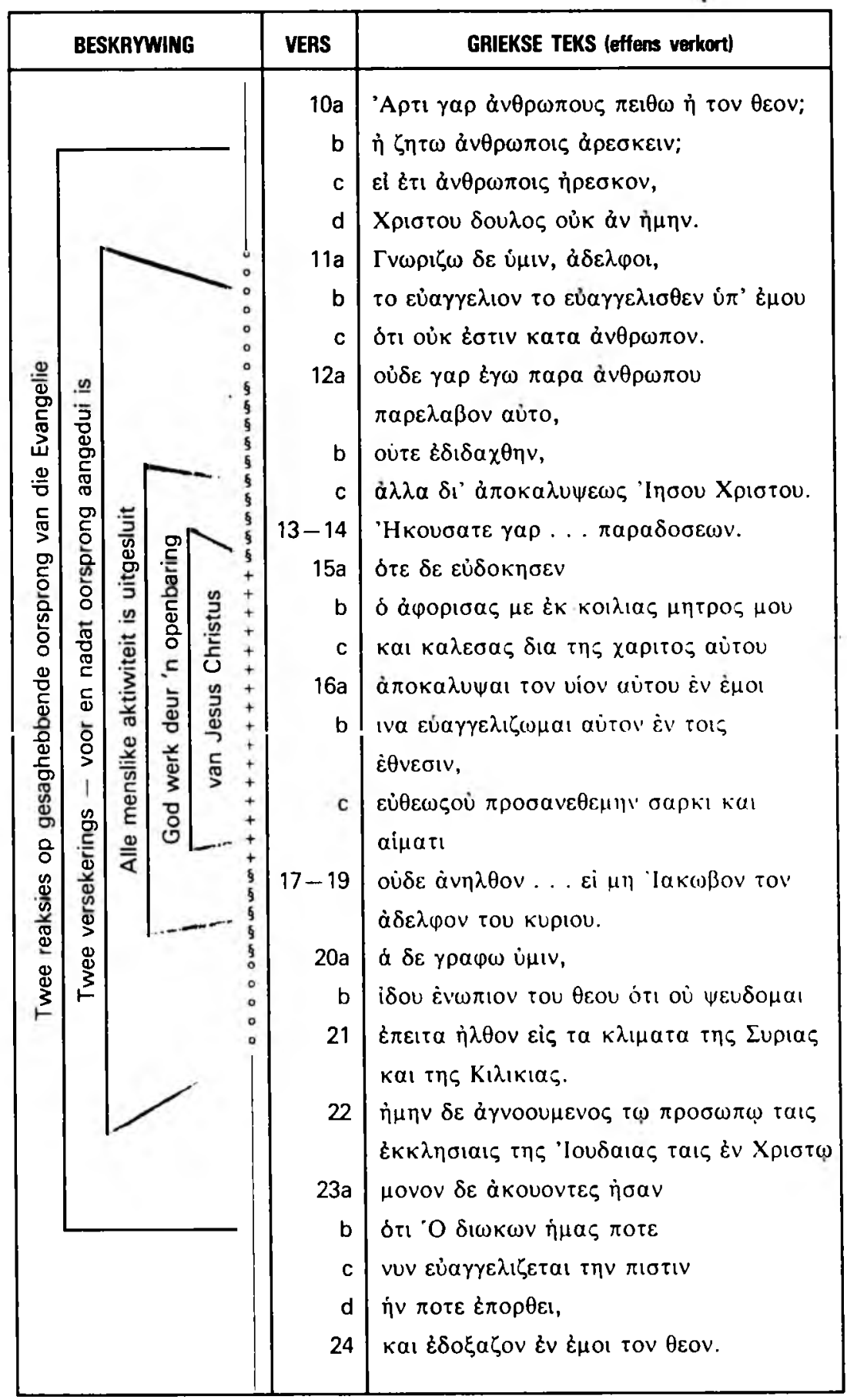


nie om afsondering van die Joodse godsdienstige gemeenskap of van die afsondering waarvan in Hd. 13 : 2 sprake is nie, maar om God se daad van voorbereiding vir sy toekomstige taak. Paulus praat ook in $\mathrm{Rm} .1: 1$ van "afgesonder tot die evangelie van God" waarmee hy veral wys op God se daad waardeur hy soos byvoorbeeld Jeremia (Jr. 1:5) eenkant geplaas is.

Paulus is dus vir die verkondiging van die evangelie bestem, en sy lewe vind daarin sy doel en hy moet hom volkome daaraan toewy (Ridderbos, 1959 : 23). Hy gee ook die rede aan waarom hy afgesonder is, naamlik om die evangelie te verkondig. God is dus die Outeur van sy dienswerk!

Die "roeping" waarvan Paulus vervolgens praat, is nie identies met die afsondering nie maar verwys na die gebeurtenis by Damaskus. Dit is nie net tot die redding van sy persoon beperk nie, maar die roeping sluit veral die bediening van genade in. Hier word die roeping spesifiek aan God toegeken, en blykens vers 12 werk die Vader en die Here Jesus Christus beide in die roeping. As vervulling van God se ewige doel roep Hy vir Saulus, wat die kerk vervolg het, tot 'n lid van die gemeenskap van Christus; Hy roep hom wat Christus verloèn het, as 'n apostel, en daarom voeg Paulus met groot klem hierby dat God hier in sy genade gehandel het (Duncan, 1955 : 27). "Genade" is die vrye en onverdiende liefde en barmhartigheid van God, en vir Paulus sluit dit ook 'n openbaring in, want dit gee hom 'n totaal nuwe begrip van God en daarom ook van homself (Wood, $1972: 23$ ).

By die outorisering van Paulus neem God dus die inisiatief en Hy doen dit uit vrye welbehae (vgl. $1 \mathrm{Tm} 1: 12-14$ ). Ten spyte van wie Paulus is en hoe sy verlede daar uitsien, het God hom vir sy besondere doel eenkant geplaas en hom op sy tyd uit genade geroep. Hierdie een woord, genade, gee konkrete uitdrukking aan God se inisierende werk, en dit bly dwarsdeur Paulus se prediking die energiebron waaruit hy sy inspirasie kry.

2.1.2.3 God openbaar in Paulus sy Seun (Gl. 1: 12b, 16a)

Dit het God behaag - God, wat die inisiatief geneem het - om sy Seun in Paulus te openbaar. Met hierdie woorde word die bron of oorsprong waaruit Paulus se gesag voortkom, nog verder omskryf.

In vers $16 \mathrm{a}$ word God se besondere handeling teenoor Paulus beskryf. Die infinitief a pia afhanklik nie. God het sy genade baie konkreet betoon, naamlik deur sy Seun in Paulus te openbaar.

'n Openbaring is 'n onthulling van God oor 'n saak buite die bereik van die mens se begripsvermoè. In vers $12 \mathrm{~b}$ word $a \pi \circ \kappa \alpha \lambda \cup \psi \varepsilon \omega \zeta$ sonder 'n lidwoord gebruik, wat of onbepaald "'n openbaring" mag wees of kwalitatief gebruik kan word om die metode waardeur die evangelie gegee is, aan te dui. Wat met sekerheid gesê kan word, is dat die openbaring of apokalips waarvan die apostel hier praat, 'n bonatuurlike verskynsel was, dit wil sẻ 'n daadwerklike verskyning van die Here uit die hemel (Hd $9: 3-7 ; 26: 12$ $-19)$. Op ander plekke plaas Paulus hierdie gebeurtenis op dieselfde vlak as die verskynings van die opgestane Christus (1 Kor. $9: 1 ; 15: 8$ ). Ridderbos (1976 : 59) is oortuig dat Paulus hier na die gebeurtenis by Damaskus verwys.

Dit was dus nie net ' $n$ innerlike openbaring in die binneste van die apostel nie maar 'n uitwendige verskyning van Christus wat ook die opening van Paulus se oẻ insluit ( 2 Kor. $4: 6$ ), sodat hy die Here Jesus as Seun van God kon erken (Greijdanus, 1953 : 40). In die openbaring van Jesus Christus lê nie 'n mededeling van 'n sekere hoeveelheid kennis van die inhoud van die 
evangelie nie, maar die geweldige feit dat God en Christus Self Jesus as die Seun van God onthul. Paulus se kennis van Christus as Seun van God berus op God se welbehae om die opgestane Christus aan Paulus te toon. Sy evangelie is op so 'n wyse regstreeks aan hom gegee, omdat God in sy lewe ingebreek het en aan hom 'n besondere openbaring gegee het (Duncan $1955: 26$ ).

Daar is baie uiteenlopende standpunte oor die vertaling en verklaring van die $\varepsilon v \mu$ or in vers $16 \mathrm{a}$, en die belangrikste is ten gunste van die vertalings "in my" waarin die innerlike verandering beklemtoon word, "aan my" en "deur my", waar $\dot{\varepsilon} v$ oo die dativus instrumentalis vervang. Paulus is nie net instrument of kanaal waardeur die evangelie deurgegee word nie, maar sy prediking is self openbaring van Jesus Christus se goddelike mag as Seun van God.

Paulus grond sy gesag nie net op die inisiërende werk van God nie, maar ook op God se unieke onthulling van Jesus Christus as opgestane Seun van God in hom, aan hom en deur hom.

Ef. $3: 1-13$ werp nuwe lig op die oorsprong van die gesag, veral in drie opsigte: Die eerste is dat Paulus se amp en prediking as 'n gawe van genade deur God gegee is en daarom geen ander oorsprong as God het nie. Die tweede is dat God in sy krag Paulus se prediking in werking gestel het en so die kragbron van sy prediking bly. En die derde is dat die openbaring alleen deur die werking van "die Gees van wysheid en openbaring" moontlik gemaak word.

2.1.2.4 Sy evangelie is nie van menslike oorsprong nie

(GI. 1: 11b, 12a, 16b-19)

Die volgende gedagte wat uit die gedagtestruktuurontleding die aandag vra, is die feit wat hy in vers $11 \mathrm{~b}, 12 \mathrm{a}$ en $16 \mathrm{~b}-19$ vooropstel. Dit is die gedagte dat sy evangelie nie van menslike oorsprong is nie en hy ook nie deur menslike bemiddeling sy evangelie ontvang het nie.

Hy sê dat die evangelie nie 'n produk van menslike ontwikkeling is nie, dat dit nie deur menslike motiewe voortgebring is nie en dat sy boodskap nie van menslike oorsprong is nie (Blight, $1970: 125$; Burton, $1948: 38$; Duncan, $1955: 22$ ). Die sinsnede (vers 11c) is sterker as "volgens oorlewering van mense" (Kol. 2: 8) of "leringe van mense" (Kol. 2: 22). Dit sê positief dat die evangelie ver buite die menslike vermoë is. Hierdie gedagte dat dit nie deur die mens voortgebring is nie, word deur die weglating van die lidwoord voor mens en die byvoeging van vers 12 nog verder versterk.

Die evangelie was nie iets wat aangeleer kon word deur dit oor en oor op te sê soos Paulus sy Rabbynse opleiding in die skool van Gamaliel in Jerusalem gekry het nie. Paulus het die evangelie nie deur middel van akademiese opleiding verkry nie en dit is ook nie langs die weg van tradisie van vader na seun, van een geslag na die ander deurgegee en ook nie deur onderrig van leermeester na leerling nie.

As Paulus in vers $16 \mathrm{~b}$ die argumente vir sy onafhanklikheid ten opsigte van die evangelie voortsit, praat hy van die onmiddellike fase nadat hy die openbaring by Damaskus ontvang het. Dit was so 'n geweldige openbaring wat die posisie van Israel, die toekoms van die volk en die gemeente so ingrypend raak dat dit nie vreemd sou wees as Paulus onder hierdie omstandighede eers die Twaalf geraadpleeg het nie. Tog het hy in die uitoefening van sy opdrag onmiddellik die beleid gevolg om hom nie vir raad tot mense te wend nie. 
Paulus se openbaring is nie verander of aangevul deur addisionele inligting wat hy op hierdie manier verwerf het nie (Guthrie, $1969: 71$ ). Daarom het hy geen kontak met die apostels gesoek nie maar hulle eerder ontwyk en hulle selfs nie geleentheid gegee om invloed op hom uit te oefen nie.

Samevattend kan dus gesê word dat Paulus teenoor die klaarblyklike beskuldiginge van die Judaïste in vers 10 in vers $11,13,16-19$ onomwonde stel dat geen mens op enige wyse by die ontvang van die openbaring betrokke was nie. Hy het die openbaring van God self ontvang en onmiddellik ' $n$ "strategie" uitgewerk om geen mens te raadpleeg nie, en daarom het hy die Twaalf 'n lang tyd doelbewus vermy.

2.1.2.5 Wil hy met sy prediking mense behaag (Gl. $1: 10,16 \mathrm{~b}, 21-24)$

Paulus het nou die gemeente op 'n baie diepsinnige wyse gelei om die oorsprong van die gesag te begryp. Daarmee het hy tegelyk die Judaïstiese aantygings weerlê wat beweer dat sy evangelie nie regstreeks van God kom nie. Die ander beskuldiging, naamlik dat hy vir homself aanhangers wil verwerf, beantwoord hy ondubbelsinnig in vers $16 \mathrm{~b}$ en 24 .

Onmiddellik nadat Paulus van die bron van sy evangelie, naamlik God en sy openbaring, gepraat het (vers $15,16 \mathrm{a}$ ), vervolg hy in vers $16 \mathrm{~b}$ met 'n doelsin waarin hy aantoon met watter doel die openbaring aan hom gegee is. Met iva gee Paulus juis nie sy eie oorwegings weer nie maar praat hy van wat God reeds onmiddellik by sy roeping aan hom te kenne gegee het. Sy besondere aanwysing was om die evangelie aan die $\varepsilon \delta v \eta$ te preek, want dit is in ooreenstemming met die plan van God (vgl. vers 15) (Duncan, 1955 : 28). Paulus is daarvan bewus dat God se afsondering, roeping en openbaring 'n voortgesette prediking van die evangelie as doel gehad het. Dit doen Paulus met soveel oorgawe dat die mense wat vroeër deur hom vervolg is, God dank en loof ter wille van dit wat Hy in Paulus gewerk het. Dit doen hulle Ev $\varepsilon$ coo, want hulle vind in Paulus "geleentheid" en rede om God te prys (Schütz, $1975: 136$ ).

\subsubsection{Gevolgtrekking uit Galasiërs}

2.1.3.1 God die diepste bron van sy gesag

Op elke plek in Paulus se Briewe wat hier ondersoek is om die oorsprong van sy gesag vas te stel, noem hy God as die diepste Bron van sy gesag. Dit is God se ewige raad, sy handelinge dwarsdeur Paulus se lewe, sy roeping en aanstelling, sy gee van die openbaring, sy gawe van genade wat meebring dat Paulus met gesag die evangelie verkondig.

\subsubsection{Christus se openbaring}

Vir Paulus is dit uiters belangrik dat Christus in en aan hom 'n openbaring gegee het. Hy herlei sy gesaghebbende prediking telkens terug na die openbaring by Damaskus, waar hy die lewende, opgestane Christus gesien het. Dit is vir hom van soveel belang omdat hy nie tydens Jesus se aardse lewe Christus as Here bely het nie.

\subsubsection{Paulus se Apostelskap}

Dit is vir Paulus belangrik dat hy met ampsgesag beklee is, maar nêrens kon die indruk verkry word dat dit vir hom geheel en al deurslaggewend is nie. Hy laat in sekere briewe selfs sy ampsbenaming "apostel" heeltemal weg. Die selfbekendstelling gee waardevolle inligting, en Paulus is die enigste wat homself met dubbelsterk naam "geroepe apostel" noem. Die ondersoek na die oorsprong of fundering van die gesag is egter nie afgehandel as die naam "apostel" in besonderhede ontleed is nie. 
2.1.3.4 Gesagsvraag beslissend vir ontvouingsprediking Galasiërs is die oudste van Paulus se briewe en die eerste van die ontvouingsprediking. Die aandag wat Paulus in hierdie brief aan sy gesag gee, toon die belangrikheid van die gesagvraag vir die regte verstaan en aanvaarding van die prediking in hierdie fase van die openbaringsgeskiedenis.

(Word vervolg) 